\title{
Corrigendum: Biased signaling of protease-activated receptors
}

\author{
Peishen Zhao ${ }^{1}$, Matthew Metcalf ${ }^{1}$ and Nigel W. Bunnett ${ }^{1,2 *}$ \\ ${ }^{1}$ Monash Institute of Pharmaceutical Sciences, Parkville, VIC, Australia \\ 2 Department of Pharmacology, University of Melbourne, Melbourne, VIC, Australia \\ *Correspondence: nigel.bunnett@monash.edu
}

\section{Edited by:}

Michael Weiss, Case Western Reserve University, USA

Reviewed by:

Charles Roberts, Oregon National Primate Research Center, USA

Michael Lawrence, The Walter and Eliza Hall Institute of Medical Research, Australia

Keywords: PARs, proteases, biased signaling, $G$ proteins, $\beta$-arrestins, signal transduction

\section{A corrigendum on}

Biased signaling of protease-activated receptors

by Zhao P, Metcalf M, Bunnett NW. Front Endocrinol (2014) 5:67. doi:10.3389/fendo. 2014.00067

Figure 3 shows a snake diagram of the Nterminal amino acid sequence of human protease-activated receptor (PAR2). It indicates the sites at which different proteases cleave PAR2. These sites are correct. The error is that we accidentally repeated a sequence of amino acid residues (11-16, GAAILL) in positions 17-22 of the snake diagram. We wish to replace the snake diagram with the correct version.

This minor correction does not affect our discussion or conclusions.

Conflict of Interest Statement: The authors declare that the research was conducted in the absence of any commercial or financial relationships that could be construed as a potential conflict of interest.

Received: 13 November 2014; accepted: 09 December 2014; published online: 06 January 2015.
Citation: Zhao P, Metcalf $M$ and Bunnett NW (2015) Corrigendum: Biased signaling of proteaseactivated receptors. Front. Endocrinol. 5:228. doi: 10.3389/fendo.2014.00228

This article was submitted to Molecular and Structural Endocrinology, a section of the journal Frontiers in Endocrinology.

Copyright $\odot 2015$ Zhao, Metcalf and Bunnett. This is an open-access article distributed under the terms of the Creative Commons Attribution License (CC BY). The use, distribution or reproduction in other forums is permitted, provided the original author(s) or licensor are credited and that the original publication in this journal is cited, in accordance with accepted academic practice. No use, distribution or reproduction is permitted which does not comply with these terms.

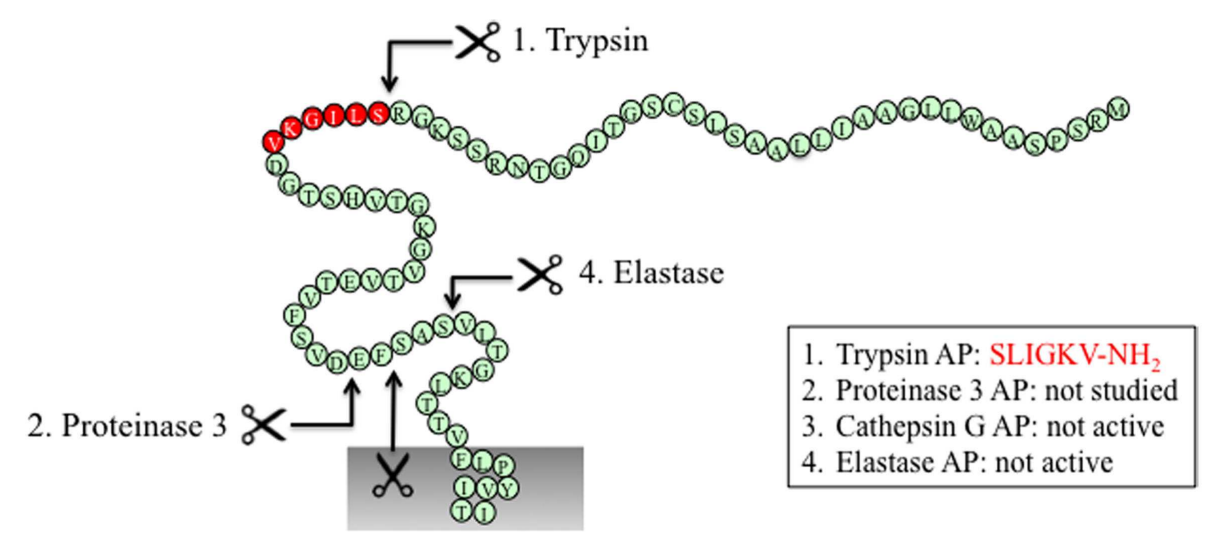

3. Cathepsin G

FIGURE 3 | (corrected). 